\title{
HENRY MARSHALL (1775-1851) AND THE HEALTH OF THE BRITISH ARMY
}

by

\author{
RICHARD L. BLANCO
}

Although Dr. Henry Marshall wrote extensively in the post-Waterloo era about the health of soldiers, relatively little has been written about his influence on military medicine. ${ }^{1}$ Marshall was a respected naturalist, a gifted historian, the first medical officer in the British army to compile vital statistics of troops garrisoned throughout the Empire, ${ }^{2}$ and he was the foremost early Victorian advocate of army reforms to benefit enlisted men.

Marshall was born a farmer's son in the parish of Kilsyth, Scotland, where his uncle, the Reverend Robert Rennie, wrote a statistical account of the local population. The young Scot received his professional education at the University of Glasgow where he formed a close friendship with a Professor of Anatomy, Dr. James Jeffray. In 1803 Marshall began his service career as a surgeon's mate in the Royal Navy, but in 1805 he joined the Forfarshire Militia as an assistant surgeon. He soon exchanged to the 89th Regiment which participated in expeditions (1806-1808) to Cape Town and to Buenos Aires. Marshall then accompanied the 89th to Colombo in 1808 where be became, successively, a regimental surgeon, a staff surgeon, and in 1816, a senior medical officer. While in the East Indies, Marshall accumulated data about the incidence of mortality in the troops resulting from disease in the tropics, he pondered the significance of the death and sickness rates extracted from his

${ }^{1}$ For information about Marshall, see Edinb. med. surg. J., 1851, 76, 489-92; N. Br. Rev., 1853, 19, 213-26; John Brown, Locke and Sydenham with Other Occasional Papers, Edinburgh, Thomas Constable [n.d.], pp. 247-90; Dictionary of National Biography, London, Oxford University Press, 1937-38, vol. 12, 1122-23 (hereafter cited as D.N.B.); A. Peterkin and W. Johnston, Commissioned Officers in the Medical Services of the British Army, 1660-1960, London, Wellcome Historical Medical Library, 1968, vol. 1, p. 173; and John D. Comrie, History of Scottish Medicine, London, Baillière, Tindall \& Cox, 1932, vol. 2, pp. 747-49.

In the late eighteenth century, write Charles Singer and E. A. Underwood, 'there was, as yet, but one section of public life in which scientific principles of preventive medicine could be applied. Only in the Army and Navy were sufferers from disease under adequate control and observation, and only there were proper statistics of sickness and health available. Thus, some of the most important movements in preventive medicine, both in Great Britain and other countries, were initiated by naval and military surgeons.' $A$ Short History of Medicine, New York, Oxford University Press, 1962, p. 181. The practice in the British army of compiling medical returns (a statistical tabulation of the number of sick, dead, and discharges from medical care in a regiment) evidently was not required from medical officers until the Peninsular War, and it was not standardized until 1816. However, numerous army surgeons in the late eighteenth century, like Thomas Dickson Reide who wrote A View of the Diseases of the Army in Great Britain, America, the West Indies ... (1793), and Dr. Robert Jackson (1750-1821), a prolific writer on military hygiene, compiled such records for their own edification. Marshall noted that 'Mr. Reide was, so far as I know, the first military medical officer who published returns of the sick and mortality of the corps to which he belonged ... Yet ... he draws no definite conclusions; and hence they do not admit of being easily compared with other medical returns.' Edinb. med. surg. J., 1833, 40, 36-37. Jackson wrote that 'a correct return of the sick of armies ... continued through a series of years, cannot be otherwise regarded than as documents of importance. They not only afford to physicians information on the subject of health and disease, and relative mortality among disease, but they supply very valuable and accurate materials for enabling statesmen and general officers to form accurate calculations, whether relative to productive labor, or to destructive foreign war.' Quoted by Marshall, ibid., 307-8. 


\section{Henry Marshall (1775-1851) and the Health of the British Army}

monthly regimental returns, and he compiled botanical and sociological information about his exotic Ceylonese environment.

During his service in Ceylon, this inquisitive surgeon published accounts of his medical experiences. Describing an unsuccessful attempt to cure a patient of hydrophobia, Marshall stressed the necessity of tabulating information from case histories. 'To obtain a perfect knowledge of any disease,' he explained in his first published article, 'a regular series of well-authenticated facts contributes greatly. The proximate cause of hydrophobia is so obscure, and its symptoms so difficult to subdue, that we cannot be too diligent in collecting plain statements . . ${ }^{3}$ After participating in the Second Kandyan War (1815-1818), Marshall wrote a fascinating essay about the problems he encountered in supervising the vaccination of the Kandyan peoples of the interior highlands. ${ }^{4}$ Early in his career, therefore, Marshall demonstrated a desire to collect information about disease from his patients. He also revealed an empirical attitude toward medicine-a scepticism of traditional systems of monistic pathology of disease and an emphasis on more accurate clinical observation and more detailed autopsies that developed during the new era of hospital practice. ${ }^{5}$ As Philip D. Curtin suggests:

European medicine was moving in new directions. Even though the germ theory of disease and cellular structure of the body were still unknown, the rationalism of the Enlightenment came belatedly into medicine toward the end of the eighteenth century ... . During the Napoleonic wars, doctors accustomed to hospital work went to the tropics with the armies, and the new generation of military doctors took with them the new precision, the new techniques, and a knowledge of the new work in the basic sciences.

Typical of many army surgeons stationed in tropical countries, like Dr. Andrew Smith (the future Director of the Army Medical Department from 1851-1858) in South Africa who became a famed zoologist and anthropologist, ${ }^{7}$ Marshall revealed

s Edinb. med. surg. J., 1814, 10, 27. Heretofore the Army Medical Board had generally required detailed financial statements of medicinal and hospital costs from army surgeons, and it had not required professional medical reports on the prevention and cure of sickness in a regiment. During the Napoleonic Wars, wrote Sir James McGrigor, the Director-General of the Army Medical Department (1815-51), the Army Medical Board demanded the most minute and scrupulous attention ... paid to 'the number of ounces of soap, salt, oatmeal, etc. . . . In short, nothing with regard to professional duty in the interests of science was noticed unless there happened to be an extraordinary mortality in the camp .... In the army, at this period . . . medical officers were not taught to take advantage of and to treasure up facts. They kept no regular register or records [of patients] ... . Hence, relatively little attention was paid to the results of new remedies, post-mortem reports, or commentaries on prevailing diseases, McGrigor continued, with the result that the surgeon's 'professional duty was not considered the most important of his duties, or that which recommended him to his superior'. The Autobiography of Sir James McGrigor, Bart., Late DirectorGeneral of the Army Medical Department, London, Longman, 1861, pp. 178-93, passim. When McGrigor became Director-General, the Lancet $(1850$, ii, 427), noted: 'He found that no professional records of the health condition of the army, or its diseases, or their treatment existed, no records except those of a fiscal nature had been made ...

Ibid., 1823, 19, 71-77.

5 For an enlightening discussion of the changes from $1800-1830$ in medical concepts, the development of a critical logic, and 'the shift from a generalized to a localized pathology,' as S. W. F. Holloway terms it, see his 'Medical education in England, 1830-1858: a sociological analysis', History, October, 1964, pp. 299-324. See also Richard H. Shryock, 'Medicine and public health', in Guy S. Métraux and François Crouzet (eds.), The Nineteenth-Century World, New York, New American Library, 1963. pp. 193-203.

- The Image of Africa, British Ideas and Action, 1780-1850, University of Wisconsin Press, 1964, pp. 181-82.

7 Percival R. Kirby, Sir Andrew Smith, M.D., K.C.B.-His Life, Letters and Works, Amsterdam, A. A. Balkema, Amsterdam, 1965, passim. 


\section{Richard L. Blanco}

his scientific curiosity by his accurate botanical observations of Ceylon's major export-cinnamon. In 1817, Sir Joseph Banks, the renowned botanist and President of the Royal Society (1778-1820) presented Marshall's essay 'A Description of the Laurus Cinnamomum' to the Society. In this article, Marshall described the cultivation, harvesting, marketing, and history of cinnamon, and he even inquired into the philological derivation of the word 'cinnamon'.8 Praising the industrious Scot for his knowledge and originality, the prestigious Edinburgh Medical and Surgical Journal claimed that heretofore 'a number of errors were prevalent respecting the exact tree or trees from which true cinnamon is produced. Some of these had been fostered by Burnam and Linnaeus ... These mistakes Dr. Marshall corrected so completely, that his descriptions have been followed by botanists in general.'?

In an article less scholarly but possibly enlightening to colleagues unfamiliar with the problems of adapting to warm climates, Marshall commented about the utility of the remarkable coconut tree. 'No single vegetable production in the countries which produce it equal the coco in value to the inhabitants,' he noted. From the bark and palm leaves, Marshall explained, the British in Ceylon constructed hospitals for convalescent troops. The coco had many other uses-the leaves were fed to elephants, the roots provided material for baskets, and the nut gave food, oil for candles, and yarn for cordage and mattress stuffing. And men appreciated the wondrous coconut tree for still another reason. The fruit and flowers were crushed into a sweet juice which supplied thirsty soldiers with the semi-fermented beverage known as 'arrack', or the fermented brew 'toddy'. 10

Such observations about his tropical habitat provided Marshall with material for his first book, Notes on the Medical Topography of the Interior of Ceylon (1821). ${ }^{11}$ The usual array of temperature charts and meteorological abstracts in the work seemed to typify studies of medical topography fashionable in the 1820 s and 1830 s which were based on a belief 'that different diseases were peculiar to distinct geographic environments'. ${ }^{12}$ But Marshall's study had broader implications. He wrote perceptive commentaries on the customs of the Kandyans, described their prevailing diseases, their practice of medicine, and included a translation from the Sinhalese language of the ancient 'Book of Medicine'.

More pertinent to his concern for the welfare of soldiers, however, were detailed case histories and disease and mortality tables of the troops-Europeans, MalayanJavanese, Africans from Mozambique, and Indians from Madras. As Marshall indicated: 'I consider the Tables and Returns the most interesting portion of the Notes.' 13

The origins of cholera, supposedly caused by 'miasma' in tropical air, particularly

8 Ann. Philos., 1817, 10, 241-56, 347-65.

- Edinb. med. surg. J., 1851, 76, 491. In a revision of his original article on cinnamon, Marshall indicated that he had been employed (evidently in addition to his military duties) as an agent supervising the grading and baling of cinnamon for the British East India Company in Colombo, Edinb. New Philosoph. J., 1839-40, 28, 27-32.

10 Edinb. med. surg. J., 1833, 39, 252-53.

11 The complete title is Notes on the Medical Topography of the Interior of Ceylon; and on the Health of Troops employed in the Kandyan Provinces, during the Years, 1815, 1816, 1817, 1818, 1819, and 1820: with Brief Remarks on the Prevailing Diseases, London, Burgess \& Hill, 1821.

12 Curtin, op. cit., 352.

18 Marshall, Notes on... Ceylon, vi. 


\section{Henry Marshall (1775-1851) and the Health of the British Army}

confounded him. 'The propagation of cholera did not appear to be in any degree affected by changes of weather, or by considerable transitions of temperature,' he declared. Cholera appeared 'on the humid and sultry flats near the sea . . ., and in the cool highlands. 'It prevailed with as much severity while torrents of rain were falling, as it did when the air was dry, hot, and parching. Hence every endeavour to trace a connection between the disease and an obvious condition of the atmosphere became completely futile.'14

Although critical of some portions of the book dealing with disease, the prominent Medico-Chirurgical Review stated that Marshall's contribution is creditable to his talents as an observant and intelligent surgeon. We recommend the work to every surgeon about to embark for our East Indian possessions.' ${ }^{15}$ The great merit of the book, commented Marshall's close friend, Dr. John Brown of Edinburgh, in an article on the life of his fellow Scot, "consisted in the numerous statistics it contained regarding mortality and disease of the troops-a new feature in medical works at the time it was published.'16

Transferred home in 1821, Marshall served four years as staff surgeon at army garrisons in Edinburgh and in Chatham. Then from 1825 to 1830 , he supervised the medical inspection of recruits at the Dublin military depot. In 1830 , the veteran surgeon was promoted to the rank of deputy inspector-general of hospitals shortly before he retired on half pay from active duty. From his home in Edinburgh, Marshall, who married in 1832, wrote a steady stream of books and articles that would earn him a reputation as a statistician and as a humanitarian.

In fact, he had continued his interest in statistical research, commenced in Ceylon, by publishing in 1823 Observations on the State of Health of the Troops in North Britain, a pioneering attempt to classify numerous ailments affecting European soldiers for a seven-year period. Explaining the difficulties that confronted a surgeon in acquiring comparative statistical data on the health of civilian populations (which 'can never or rarely be procured'), Marshall explained that army medical returns 'possess a precision superior, perhaps, to all others on account of the exactness with which the [troop] strength may be ascertained . . . ${ }^{17}$

Aware of the limited information available concerning standards of physical examinations for enlisted men, and of the difficulties confronting inexperienced army surgeons in detecting the concealment of bodily defects by recruits and in discovering numerous frauds perpetrated by veterans desperate for discharge, Marshall in 1828 published Hints to Young Medical Officers, virtually the first work of its kind written in English. Urging his colleagues to inspect soldiers scrupulously, he warned that 'I never knew a medical officer, who would not readily admit that he had, at one time or another, been outwitted by their fallacious assumptions, and might again be deceived'. ${ }^{18}$

14 Ibid., p. 191.

16 Brown, op. cit., p. 247.

18 Hints to Young Medical Officers of the Army on the Examination of Soldiers; with Official Documents and the Regulations for the Inspection of Conscripts for the French and Prussian Armies, London, Burgess \& Hill, 1828, p. 96. 'The simulation of infirmities is much practised by recruits, although it is a species of fraud which is by no means confined to young soldiers ... Perhaps nine-tenths of the recruits regret the step they have taken [i.e. enlisting in the army] and are willing to practise any fraud, or adopt any means which promises to restore them to liberty ... Some excite [sic] ulcers, others affect stammering, deformity, pain in various parts of the body, deafness, blindness, epilepsy, contractions of the fingers, lameness, etc.' Ibid., p. 89. 


\section{Richard L. Blanco}

What impressed one reviewer of the book was not only its novelty and utility, but the startling revelations about the wretched existence of enlisted men, doomed to life service in environments often inimical to health, who feigned illnesses in order to deceive their superiors. ${ }^{19}$ Recommending the volume as necessary for all medical officers in the public service, the Edinburgh Medical and Surgical Journal commented that readers accustomed to heroic tales about the glorious exploits of their sailors and soldiers 'will ... . be but little prepared to meet with the moral degradation and depravity which occasionally falls under the observation of the military and naval practitioner . ..$^{20}$

In 1832, Marshall completed a second commentary on the examination of the rank and file, On the Enlisting, Discharging and Pensioning of Soldiers, in which he urged the compilation of an official handbook on military hygiene (for none existed in the British army) and the preparation of a comprehensive statistical study of the health of troops derived from the vast accumulation of Medical Department records in London. ${ }^{21}$ In an era when British soldiers were described as 'the scum of the earth', or when regimental commanders assumed that the worst men make the best soldiers', Marshall's sympathy for the men in the ranks, a distinct feature of this work, demonstrates a sensitivity to the plight of soldiers that was rare for the $1830 \mathrm{~s}^{22}$ Although the aristocratic and middle classes generally considered troops as vicious and unworthy of redemption, Marshall believed that, with patience and understanding, the morality of soldiers could be improved.

Marshall reiterated this theme in an article in which he and two co-authors described the characteristics of numerous feigned diseases. Urging medical officers not to tolerate 'notorious malingerers' who shirked their duty, the writers, however, ended their essay on a profound humanitarian tone:

But when instances of deception become frequent in any country, in any garrison or station ... the question may very reasonably present itself-is there not something wrong in the arrangement of the place, in the government or administration ... in which frequent deceptions such as false injuries are resorted to; - -something which, acting injuriously on the bodies or the minds of men, is therefore not beneath the consideration of the medical officers ...., who alone can appreciate the mischief, and by whose mediation alone it is likely to be remedied? The privilege conferrred by their profession, of being the friends of mankind, is one which ought not to be willingly resigned. ${ }^{23}$

Marshall also considered the vexing problem of falsified pension claims by disabled veterans. Before a soldier was discharged, a regimental board, including a medical officer who determined the soldier's fitness for duty, investigated the man's service record. Soldiers enlisted for life, or until they were discharged, owing to mental or

${ }^{10}$ N. Br. Rev., 1853, 19, p. $218 . \quad 20$ Edinb. med. surg. J., 1828, 30, 181.

11 On the Enlisting, Discharging and Pensioning of Soldiers with the Official Documents on these Branches of Military Duty, Edinburgh, 1939, 2nd ed., vii. With reference to hygienic matters, Marshall wrote elsewhere: 'This information is not generally communicated in medical schools, nor has it hitherto been conveyed in a comprehensive manner by any book in the English language, although it is absolutely necessary for the efficiency of a medical officer.' Edinb. med. surg. J., 1834, 44, 42.

12 'It is no credit to Wellington,' writes E. L. Woodward (The Age of Reform, 1815-1870, Oxford University Press, 1958, 256-57), 'that he should have never used his immense authority to insist upon an improvement of the conditions under which soldiers lived. He abolished the rule under which two soldiers shared a bed, but he did little else to make barracks life tolerable.'

"Henry Marshall, J. Scot, and John Forbes, 'Feigned Diseases', in Alexander Tweedie, John Conolly, and John Forbes (eds.), Encyclopaedia of Practical Medicine, London, Sherwood, 4 vols., 1833-1836, vol II, 158. 


\title{
Henry Marshall (1775-1851) and the Health of the British Army
}

physical disabilities, at the indulgence of the Crown. Since 1806 (Wyndham's Act), discharged veterans had been entitled to a life pension; but by subsequent amendments to this law, disability, and not length of service and good conduct, constituted the major claim for a stipend from the state. Thus, a soldier could not be discharged unless he was supposedly incapacitated for army service; hence, many clever men deliberately faked diseases or injuries and falsified regimental records. A pension grant to a veteran should have been a just reward by a grateful nation for services rendered. Instead, an army discharge and a life pension were often the result of chicanery and self-inflicted injuries as hundreds of men feigned deafness, lameness, blindness or other maladies for long periods of time. As Marshall put it: 'The regulations have a tendency to encourage moral depravity. ${ }^{24} \mathrm{~A}$ drastic reform of the pension system was necessary to provide some flexibility in periods of enlistment, to eliminate the enormous degree of deceit and degradation involved in pension claims, and to dignify what heretofore had been a vicious method of obtaining discharges.

Troubled by the large number of army pensioners, by the excessive cost to the government, and by the knowledge that records had been falsified in numerous regiments stationed in Ireland, Sir Henry Hardinge, Secretary for War (1828-30, 1841-44), appointed Marshall to a special pension board to appraise documents of soldiers discharged in Britain. 'Our investigations led us to conclude.' wrote Marshall, 'that the pension list has been in no small degree augmented by dishonest means ...., by false returns of service, and the simulation of disabilities. ${ }^{25} \mathrm{He}$ stated that the board urged that:

\begin{abstract}
the soldier that has long served his country, or who has been wounded in this cause, shall continue to receive a liberal pension for life. This measure is not only equitable but politic. We are not advocates for a reduction in the rate of pensions to men who have been disabled by wounds, or who have become really infirm by the exigencies of the service while disability exists .... To advance the legitimate object of the system in question, we should be happy to see a code of regulations tending to preclude existing abuses, and to hold out an inducement to honest and meritorious behaviour."
\end{abstract}

Eliminating fictitious claims and recommending a reform of the pension system, the board supported Marshall's plan that became the foundation for a more equitable Pension Warrant which based the veteran's stipend upon length of service, wounds received in action, and condition of health determined by a thorough medical examination. ${ }^{27}$ As a result of this investigation, significant changes soon occurred in pensioning procedures. In 1833 a new Pension Warrant provided a slight increase in the daily rate of pension, established the principle that a soldier with from fourteen to twenty-one years of service could be dismissed from the service without a pension, and it also permitted a soldier having twenty-one years of service, a service disability, and a record of good conduct to be discharged with a full or partial pension. The humanitarian approach to the pension system, suggested by Marshall, was amplified by another Pension Warrant in 1839 by which men with ten years of service and distinguished records could purchase their discharges from the army. ${ }^{28}$

2 United Service Journal and Naval and Military Magazine, 1829, ii, 330. (Hereafter cited as U.S.J.)

25 Ibid., p. 317.

27 Ibid., 1842, i, 47.
26 Ibid., p. 331 .

2 Ibid., 1842, i, 529. 


\section{Richard L. Blanco}

But a more crucial matter than the pitiful pension requests of wretched old soldiers also occupied Henry Marshall. While in the East Indies, the harmful effects of excessive liquor upon the health and conduct of European troops had deeply troubled him. The army provided a ration of two drams every morning before breakfast to entire garrisons-from the youngest drummer boy to the most hardened veteran-in order to ward off 'the morning fogs, . . . to enable men to undergo great fatigue . . .', and as a medicinal 'to prevent the influence of endemic fever'. ${ }^{29}$ The North British Review lamented that 'it was the duty of soldiers to imbibe spirits under the superintendence of a commissioned officer ... Perhaps a more successful plan for converting temperate men into drunkards could not have been invented.' ${ }^{\prime 30}$ But in addition to the army allowance of 'wholesome liquor', troops could purchase spirits (arrack or toddy) at canteens and from natives. Indifferent to repeated flogging as a punishment for drunkenness, men with an unquenchable thirst would drink virtually any intoxicating potion-in the Indian Ocean a famous concoction was the explosive 'hell-blazer', and in the Caribbean a favourite brew was the debilitating 'kill-devil'.

'This quantity of spirits', noted Marshall, who evidently held no stern religious views on the evils of drink, "promotes a desire for more, and the day is spent in devising means of surreptitiously introducing liquor in the barracks . . . By the daily custom of imbibing spirituous potations, a new want is created, intemperance is established as a habit, and frequent intoxication is the result.' This passion for drink, claimed the surgeon, led inevitably to crime, disease, punishment, and to endless friction with the natives. Implying that near pandemonium occurred on 'balanceday', when the troops were paid, Marshall claimed that 'commanding officers were obliged to dispense with parades, sometimes for several days. Occasionally it was difficult that the requisite number of men be found sober to be able to mount guard.'31

Denouncing the popular legends about the regenerative powers of strong drink in the tropics, Marshall castigated what he considered an absurd practice condoned by the army: 'We instill the moral and physical poison with one hand, and hold out the lash with the other.'32 Urging the abolition of the liquor allotment to improve health, morality, and efficiency of garrisons overseas, Marshall suggested that the men be provided with the rudiments of education during their leisure. What resulted from this biting critique of a cherished army tradition? Impressed by Marshall's paper on the evils of intoxication, Hardinge took prompt action. He initiated measures by which divisional commanders received discretionary powers to limit the issue of spirits ${ }^{33}$ Obviously, the matter of excessive drinking in the army was perennial, but, at least, Marshall's candid appraisal stimulated a more rational approach to the problem.

After this temperance tract, Marshall in the early 1830s composed a series of articles advocating more attention by his colleagues to military medical returns. Using as an example the sanitary history of a regiment in India, he recommended that army

${ }^{29}$ Edinb. med. surg. J., 1834, 41, 25-26.

so $N$. Br. Rev., 1853, 19, p. 219.

81 Edinb. med. surg. J., 1834, 41, 20-21.

82 Ibid., p. 30.

ss $N$. Br. Rev., 1853, 19, p. 219. For an attempt to abolish the sale of spirits in army canteens, see Hansard's Parliamentary Debates, 3rd. Ser., 90, House of Commons, cols. 952-57, 5 March, 1847. (Hereafter cited as Hansard). 


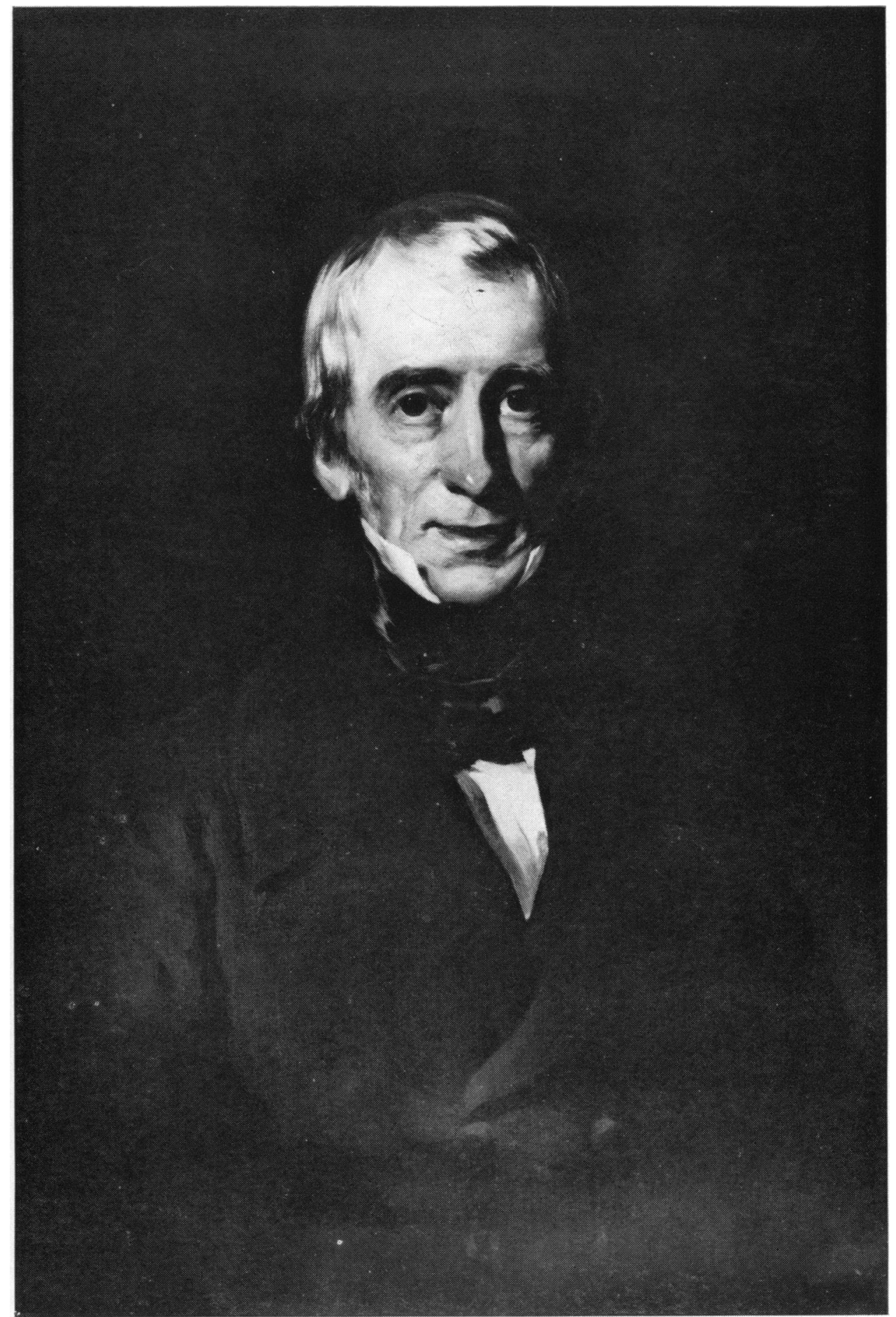

Henry Marshall, 1775-1851.

Original painting in the possession of the Scottish National Portrait Gallery, Edinburgh. 


\section{Henry Marshall (1775-1851) and the Health of the British Army}

surgeons compile standardized reports showing the mean annual ratios of sick, dead, and hospital discharges. ${ }^{34}$ Such military returns, he noted: 'are well calculated for deducing satisfactory conclusions respecting the comparative salubrity of different climates. The men of one corps, ... are similar in regard to period of life; their food, exercise, accommodation, and habits are also similar; so that when there is much greater mortality in one garrison than another, the circumstances may be chiefly attributed to climate. ${ }^{35}$

If complete medical returns of entire divisions were collected and published, he assured his readers, such statistics 'will solve many problems concerning which we are at present much in the dark, or completely ignorant. ${ }^{36}$ Why certain diseases prevailed in some areas of the world and were virtually unknown elsewhere is frequently involved in great obscurity'. ${ }^{37}$ As an example of the lack of precise information about the adaptability of Europeans to tropical climates, Marshall inquired about the available data concerning mortality rates of children born to whites in the Indies. 'I am not aware,' he admitted, 'of the existence of any statistical information before the public calculated to answer the question. ${ }^{38}$

While pondering such problems, Marshall studied the medical history of the 40,000 British troops who participated in the ill-fated Walcheren expedition (1809) to the Dutch coast during the Napoleonic Wars. Perplexed that sickness rates varied considerably from regiment to regiment, he asked, 'What can have been the cause why some corps on the same service and exposed to the same climate suffered so much more than others did?'39 Surely, he insisted, some statistical computation of this great tragedy involving thousands of fever-stricken victims should have been compiled by one of the 250 medical officers attached to this army in order to benefit 'mankind in general, and the army in particular'.40 In a commentary that revealed an empirical sense of confidence that man could eventually conquer the malignancy of nature, Marshall wrote:

Sometimes these effects [malaria] may have been inevitable, while on other occasions they seem to have been the result of neglect, inattention, or ignorance, which could not always be easily excused. We dread, and justly dread, the influence of epidemics, such as the plague and cholera, while we submit with apparent indifference to the perennial consequences of malaria in unhealthy localities, without duly inquiring whether the remote cause of a high degree of sickness and mortality might not be obviated. We endure what is expected; but when it is once shown that great sickness is not fated or unavoidable, much may commonly be done to prevent it. ${ }^{41}$

Marshall's suggestion for an official study of medical returns from army posts throughout the Empire coincided with a similar desire to publish this material by the DirectorGeneral of the Army's Medical Department, Sir James McGrigor. In fact, McGrigor

4 Edinb. med. surg. J., 1833, 39, 136. As Lancet $(1837-38,1,578)$, noted: 'it is much to be regretted that the elements of medical statistics are not taught in the schools, and that the medical officer should have been left uninitiated in the simple means of deducing the real mean strength from the monthly muster.'

as Edinb. med. surg. J., 1833, 40, 36.

so Ibid., 1833, 40, 321.

se Ibid., 1835, 44, 40-41. Marshall also wrote three articles on the health of the French army. See ibid., 1834, 42, 35-49; 1838, 50, 15-25; and 1840, 53, 69-78.

${ }^{30}$ Ibid., 1837, 48, 323.

11 Ibid., p. 325. For a recent account of the relative lack of medical histories on the Walcheren tragedy, see Bull. Hist. Med., 1968, 42, 62-79. 


\section{Richard L. Blanco}

had instigated the practice in 1816 of requiring principal medical officers to provide his office with periodical medical case histories of troops under their care, in addition to pertinent information about related environmental factors. ${ }^{42}$ 'Had such records been always faithfully kept,' McGrigor had written after his experiences in the Egyptian campaign of 1801, 'many practical points would not, as they are now, be involved in doubt and uncertainty. We should not now be so ignorant of some diseases, of the countries where we have so often made campaigns, or of which we have so long been in possession.' 43

By 1835 , about 160 volumes of such information had been accumulated, but the data had to be summarized, analysed, and interpreted in order to benefit medical science. "If all the facts relating to the prevalence of disease were arranged in tabular form,' explained the Edinburgh Medical and Surgical Journal, 'such table were more likely than any other form to furnish accurate results regarding many points on which vague and inaccurate statements only had hitherto been made.'4 It was 'my intense desire,' wrote McGrigor, 'to accomplish fully the object which I had entertained for many years, viz. to turn the reports and returns rendered by the medical officers of the army to the account of science, and the improvement of the officers themselves ... $\therefore$ Marshall's hope for official support for an investigation of sickness and mortality rates in the army came in October 1835, when Viscount Howick (Sir Henry George Grey), Secretary-at-War (1835-1839), requested that he and Lieutenant Alexander Murray Tulloch of the 45th Regiment, an authority on vital statistics, ${ }^{46}$ prepare such a report of the West Indies.

Completed in 1837, the report traced the sanitary history of the British West Indian command-Jamaica, the Bahamas, British Honduras, and the Windward and Leeward Islands-from 1816 to 1837 . It demonstrated graphically that the environment of the Caribbean had highly inimical effects on the health of troops. Compared to the average annual mortality rate of soldiers stationed in Britain of 17 per 1,000 men for a comparable period, the death rate of troops in these seemingly morbific colonies was 78.5/1,000 in the Windward and Leeward Islands, 103/1,000 in British Honduras, 107/1,000 in the Bahamas, and 143/1,000 in Jamaica. ${ }^{47}$

A valuable feature of the report was a statistical classification of disease (by a nomenclature such as 'fevers', 'diseases of the stomach and bowels', etc., which reflected the prevailing diagnostic difficulties confronting a surgeon) that provided

\footnotetext{
12 McGrigor made copious notes on the medical histories of British regiments during the Peninsular War which are in 13 volumes of Case Books and Letter Books, The McGrigor Papers, Aberdeen Medico-Chirurgical Society Library. See his important article on disease and mortality rates of British troops in Spain in Med.-chir. Trans., 1815, 6, 381-88. See also Lancet, ii, 427; Gentleman's Magazine, 1858, i, n.s. 4, 555; and Brit. med. J., 1914, p. 188.

is James McGrigor, Medical Sketches of the Expedition to Egypt from India, London, John Murray, 1804 , pp. 52-53.

" Edinb. med. surg. J., 1838, 50, 424-25.

4s McGrigor, Autobiography ...., p. 367.

40 Tulloch (1803-1864) had displayed his reforming zeal in the East Indies where he publicized the need for properly provisioning troops, and where he demonstrated to the War Office that the East India Company was cheating soldiers by payment of wages in depreciated currency, See U.S.J., if, 404-7, and D.N.B., vol. 19, 1233-34. See also his article on mortality rates of British officers in U.S.J., 1836, ii, 145-72, and his article comparing mortality rates of seamen and soldiers in Med.-chir. Rev., 1841, 35, 170-72.

"I Statistical Report on the Sickness, Mortality, and Invaliding Among the Troops in the West Indies, Parliamentary Papers, 1837-38 (138), xl, 417, pp. 5-77, passim. (Hereafter cited as P.P.).
} 


\section{Henry Marshall (1775-1851) and the Health of the British Army}

detailed information about the relative insalubrity of every British military garrison in the Caribbean.

With such evidence, the writers, accustomed to describe disease in terms of miasmatic and climatorial pathology, questioned some traditional assumptions about the physical adaptability of whites to the tropics. One such contemporary belief was that Europeans gradually became acclimatized to warm climates by a process known as 'seasoning', for it was assumed that due to 'seasoning', the sickness and mortality rates of older soldiers, accustomed to the environment, was far lower than younger men with less service in the West Indies. But, 'instead of the mortality of our troops ... decreasing with age,' stated Marshall and Tulloch, 'as has been the general impression, it increases with greater rapidity than in this country [Britain] . . ${ }^{48}$

Was continual exposure to high temperatures somehow related to the yearly decimation of rank and file? Apparently not, for the report explained that 'the range of the thermometer ... in Antigua and Barbados, is rather higher than in Dominica, Tobago, Jamaica, or the Bahamas; yet we find that the troops in the latter stations suffer three times as much as the former.' Furthermore, the mortality rate of a garrison could be twenty times greater than that of another year 'without any perceptible difference in the range of temperature'. ${ }^{9}$

Was the pestilence of the Caribbean due to excessive rainfall, or to the 'miasma' emanating from the swamps, lagoons, and marshes near many garrisons? Thus, areas inundated during prolonged rainy seasons presumably would have the greatest amount of sickness. But Jamaica had annually only one-half the rainfall of British Guiana, and yet the mortality rate of troops in Jamaica was double the rate in Guiana. Thus, concluded the statisticians, 'neither heat nor moisture can be the primary cause which influences the health of troops in the West Indies ....so

They also doubted some other explanations of disease, such as sickness caused by the lack of trade winds from July to October, or by the influence of 'miasma' from South American jungles, or by 'the exhalation or emanations from the soil'. But the writers inquired whether a garrison's location and its elevation from sea level were related to its sanitary history. Comparing the medical records of twenty-seven Jamaican stations located from the seacoast to the Blue Mountains, the report demonstrated that posts close to the sea, much as Montego Bay with a mortality of $178.8 / 1,000$ were generally the most unhealthy compared to the relative salubrity of Maroon Town, located at a height of 2,000 feet, which had a death rate for troops of 32.7/1,000.51 But the researchers were baffled that a garrison like Stony Hill, situated at an elevation of 1,360 feet, had a high mortality rate of $90.2 / 1,000$, and that some stations located on "low sandy tongues of land or peninsulas jutting into the sea . . . were comparatively free of that great killer-yellow fever. Thus, concluded the researchers, 'it must be admitted that it is exceedingly difficult, if not impossible to point out a practical rule to be followed in the choice of a healthy location for the troops. ${ }^{52}$

Shunning pretentious theories about causes of tropical diseases, Marshall and

Ibid., p. 84.

so Ibid., p. 102.

62 Ibid., p. 103. c Ibid., p. 101.

61 Ibid., pp. 51-71; 103. 


\section{Richard L. Blanco}

Tulloch concluded their study with recommendations to improve the sanitary condition of the troops: more frequent rotation of regiments from long service in the Caribbean to the cooler climate of the Mediterranean or British North America, the construction of larger and better ventilated barracks at higher elevations, some restrictions on liquor rations, suggestions for a more wholesome diet for soldiers, and the use of more black enlisted men (whose sickness and mortality rate was consistently lower at virtually every station). ${ }^{53}$

These deductions and suggestions, commented the Edinburgh Medical and Surgical Journal, 'some will regard as not remarkable for novelty or originality. They are, however, valuable in eradicating various errors, and clearing the ground, as it were, for the construction of a more substantial theory than any yet adduced. ${ }^{54}$ Such reports, announced the Lancet, a vociferous spokesman of medical reforms, "will constitute a most important acquisition to medical science; will furnish data for the solution of innumerable questions in the etiology of disease; and will inevitably lead to the salvation of thousands of lives,'55 The Times proclaimed that 'the great value of this report is the beneficial influence which it is calculated to exercise over the practical arrangements of reliefs for the regiments doing duty in the West Indies. 56 Perusing the document, along with another statistical study, the First Annual Report of the Registrar General of Births, Deaths, and Marriages (1839), The Quarterly Review claimed that 'the Military Reports are the most valuable gifts, as to the effects of climate, which have ever been made to medicine . . . ${ }^{57}$ Probably, the major influence of this study, a landmark in military medicine, was to stimulate the publication of similar reports of the health of troops in the rest of the Empire and to focus attention on the need for army reforms. As the United Services Journal noted in 1864: 'from that investigation ... may truly be dated all the amelioration of the condition of the soldier that have since been affected. 58

Additional documents on the health of troops in other areas of the Empire, an endeavour heartily supported by McGrigor, soon followed. ${ }^{59}$ In 1837 , the Director-

ss Ibid., appendix, pp. 2-7. The recommended amount of barracks space per man was 600 cubic feet compared to the prevailing average in the Caribbean of 400 cubic feet, "and prior to 1827 it was little more than half as much'. Although dietary changes for the troops occurred while the report was being compiled, Marshall and Tulloch urged that the issuance of salt pork and salt beef to troops be discontinued. They explained that: 'The ration of salt pork, can, however, scarcely be supposed to afford a sufficient dinner for a soldier; the $9 \mathrm{oz}$. of which it consists, are generally reduced by boiling to $6 \mathrm{oz}$. , which, with a pint of soup and a few vegetables, is generally all the nutriment he receives between dinner-hour, at 12 or 1 o'clock, and 7 or 8 o'clock the following morning'. Ibid., pp. 2-4.

su Edinb. med. surg. J., 1838, 50, 466.

ss Lancet, 1837-38, ii, 575. $\quad$ os Times, 29 August, 1838, p. 6.

${ }^{87}$ Quart. Rev., 1840, 66, 116. The report 'is not surpassed by anything in the records of our art ..... Brit. for. med. Rev., 1839, 8, 211. 'This report produced nothing short of a revolution in the department of military policy; it destroyed the old established notion of seasoning'. Brown, op. cit., p. 256.

${ }^{68}$ U.S.J., 1864, ii, 406.

so Using the report on the West Indies as a model, Tulloch, acknowledging the aid of Marshall, completed the following: Statistical Report .... Among the Troops in the United Kingdom, the Mediterranean, and British North America, $\dot{P} . \dot{P} ., 1839$ (166), xvi, 129; Statistical Report ... Among the Troops in Western Africa, St. Helena, Cape of Good Hope, and Mauritius, Ibid., 1840 (228), xxx, 135; and Statistical Report .... among Her Majesty's Troops Serving in Ceylon, the Tenasserin Provinces, and the Burmese Empire, ibid., 1842 (358), xxvii, 147. For a comparable development in the Royal Navy, see the recommendation on naval hygiene by Sir Gilbert Blane, and Christopher Lloyd (ed.), The Health of Seamen, Selections from the Works of Dr. James Lind, Sir Gilbert Blane, and Dr. Thomas Trotter, London, Spottiswoode, Ballantyne, 1965, pp. 175-201. See also Christopher Lloyd and Jack L. S. Coulter, Medicine and the Navy, 1200-1900, Edinburgh and London, E. and S. Livingston, 1963, vol. 4: 1815-1900, pp. 81-91, 266-67. 


\section{Henry Marshall (1775-1851) and the Health of the British Army}

General wrote to the War Secretary that: 'In my opinion, with the large field for observation and experience in every quarter of the world placed before the Medical Officers of the Army, and the means placed in their hand of enlarging the bounds of Medical Science, the public have a right to expect that the fruits of such enlarged experience and observation be laid before them by the State.' ${ }^{60}$ But Marshall inexplicably severed his official position as a compiler of statistical reports for the army in 1838 to be replaced by a young assistant surgeon in the Grenadier Guards, Dr. T. Graham Balfour, who was to play a significant role in the development of military medical statistics. ${ }^{61}$

Convinced that military medicine encompassed a responsibility for the army surgeon beyond that of the prevention and cure of disease, Marshall became the public champion of the enlisted man. He wrote a series of articles (1838-1845) in the United Services Journal and published two books, Historical Details Relative to the Military Forces of Great Britain (1842), and Military Miscellany (1846) which were spirited pleas for numerous army reforms to dignify the status of the rank and file-an improvement of the officer/enlisted man relationship, shorter periods of enlistment, education for illiterate soldiers, and a condemnation of the disciplinary code of the army.

Marshall particularly criticized the typical attitude of army officers toward their men whom they treated as criminals and degenerates. 'It is not expected that the British army consist of saints ...., but as our regiments are frequently recruited from jails, or by men who dropped from the recesses and labyrinths of vice,' he declared, 'it is earnestly to be desired that they should be instructed in their duty not only as soldiers but as men ... . Some attention to the morals of soldiers, he insisted, is as necessary as the means of preserving their health . . ${ }^{62}$ Marshall pointed out that conditions of the service-the low pay, the inhumane discipline, the prolonged period of duty overseas, the harshness of barracks life, the lack of respectable recreational opportunities-could turn even normally respectable men into brutes. But with better treatment of men by compassionate officers who sought to remove such inequities, Marshall claimed, a mass regeneration of regimental morale could result.

Lamenting the degree of illiteracy in the ranks, Marshall inquired if unlettered troops could be provided with the rudiments of an education in the army. The Foot Guards, he noted, had schools for their men. 'The principle is excellent,' he declared, 'and should be adapted in all regiments of the line . . ' in order to make soldiers 'useful and intelligent members of society.' ${ }^{\prime 63}$

Aware of the sense of helplessness that confronted a soldier who had joined the army as a youth to escape hunger, only to be trapped in long-term enlistment, Marshall

\footnotetext{
on McGrigor to Grey, 27 July 1837. The Earl Grey Papers, 3rd Earl (photocopied). The Prior's Kitchen, University of Durham.

'1 Balfour became a surgeon in the Duke of York's Asylum for Soldiers' Orphans at Chelsea in 1840 , and he was active in urging army reforms during the Crimean War. G. H. Brown (ed.), Munk's Roll, 1826-1925, London, Harrison, 1955, vol. 4, p. 124.

62 Henry Marshall, Historical Details Relative to the Military Forces of Great Britain, n.p., 1842, pp. 47-50.

os Henry Marshall, Military Miscellany; comprehending a History of the Recruiting of the Army, Military Punishments, etc., London, John Murray, 1846, pp. 94-96. 'I would strongly recommend that an adult school should be established in every regiment,' wrote Marshall, 'and that instruction should be under the superintendence of a commissioned officer', U.S.J., 1842, ii, 367.
} 


\section{Richard L. Blanco}

also questioned 'the system of life-bondage'. In order to alleviate the high rates of desertion and of punishment, would it not be more economical and more humane, he asked, to enact shorter terms of service, 'say ten years?'

But his major emphasis for army reforms centred on publicizing the brutal punishments inflicted upon men for the slightest infraction of a harsh disciplinary codeflogging, branding, imprisonment, transportation, or service with a penal corps in Africa. The purpose of such archaic and illogical degradation of men, in which a punishment often exceeded the degree of crime, explained this disciple of Beccaria, was not 'to make men virtuous and good, but to produce instant obedience'. Instead of repressing crime, he insisted, barbarous punishments since the Middle Ages 'have failed to a much greater degree than penalties of a comparatively lenient character'. ${ }^{66}$ Branding, whipping, maiming have 'never reformed a corps, but they have ruined many a man'. ${ }^{67}$ Does not 'the cat-o'-nine tails defeat the object of punishment?'68 Hoping to abolish flogging and branding under the pressure of public opinion, Marshall noted that the degree of crime in civilian society could be lowered by moral training, educational improvements, and a higher standard of living. 'May we not presume that offences may be prevented in the army more effectively by raising the character of soldiers and by meliorating their condition . . .? 69

Owing to a tragic circumstance, Marshall's plea for army reforms received unexpected publicity. On 11 July 1847, Private Frederick John White of the 7th Regiment of Hussars, sentenced by a court martial to a punishment of 150 lashes, died at Hounslow Heath from injuries resulting from the whipping. The event shocked Parliament and brought bitter condemnation of the vicious punishment from The Times. ${ }^{70}$ During heated debates in the House of Commons on the need for more humane treatment of soldiers, numerous references were made to Marshall's recent works. ${ }^{71}$ The immediate result of the Hounslow incident, which was castigated in numerous editorials by Thomas Wakley, the editor of the Lancet $^{.2}$ was to force the embarrassed Horse Guards to restrict flogging henceforth to a maximum of fifty lashes.

Although the practice of flogging was not abolished in the army until 1881, later

o4 Marshall, Military Miscellany, pp. 102-4.

o6 Ibid., p. 131.

68 Ibid.

70 See The Times, 2 July 1846, p. 2 , and 7 July, p. 8 for commentaries on the flogging and Marshall's influence. The Brit. for. med. Rev. (1847, 23, 169), commenting on Military Miscellany, stated that: 'The army owes a debt of gratitude to our author for having exposed many abuses and called attention to the means of ameliorating the soldiers' lot.' Reviewing the same work, the Med.-chir. Rev. (1846, 45, 122) stated that: 'And surely there is no occupation, in which medical men can more profitably fulfil their beneficient mission, than in using all their professional influence and authority to plead the cause of the suffering and oppressed against the heartless neglect or tyrannical severity of irresponsible taskmasters.'

${ }^{71}$ Hansard, 88, House of Commons, cols 387-88, 7 August 1846. In a speech condemning flogging, Mr. W. Williams of Coventry explained that 'this information he has obtained from Mr. Marshall's recent book on military affairs. The fact was that without the assistance of Marshall's valuable work he could have not come forward with so full a statement . . . Ibid., 413-14.

72 Lancet, 1846, if, 72-79; 540-42; 570-71. Woodward (op. cit., p. 257) notes that: 'Flogging by order of a regimental court martial was restricted in 1812 to 300 lashes, though a district or general court could still order an unlimited number of lashes ... In 1832 the sentences of district courts martial were limited to 300 lashes, and of regimental courts to 100 lashes. Four years later further restrictions were imposed; in 1850 the punishment was limited to 50 lashes. In 1867 flogging was forbidden except for offences in war time; the order was shortly afterwards extended to the Navy.' 


\section{Henry Marshall (1775-1851) and the Health of the British Army}

annual regimental returns show a steady decline in the number of men whipped. Gradually, in Marshall's last years, a series of reforms for the enlisted man was enacted. The War Office more frequently rotated troops from the Indies as normal procedure, constructed better barracks, established army schools, ${ }^{78}$ and initiated a practice of an evening meal of coffee and bread. Good Conduct Pay of one penny after five years of service, provided in the Pension Warrant of 1845, was offered the men, as well as regimental libraries, savings banks, and opportunities for a limited number of enlisted men to become commissioned officers. And in 1847, the Limited Enlistment Act provided for a ten-year term in the infantry or for twelve years in the cavalry.

To what degree these changes were due to Marshall's labour is, of course, difficult to state, especially when virtually every traditional institution in Britain, like the army, was being modified during the Age of Reform. But certainly he was influential with Fox Maule, Secretary at War (1851-52), the sponsor of the Limited Enlistment Bill, who claimed that Marshall's Military Miscellany 'is my Bible in all that relates to the welfare of the soldier'. And Hardinge, who became Commander-in-Chief (1852-56) informed Marshall that: 'Your book should be in the hands of every army surgeon, in every orderly room in the service."74

Marshall's last published work was Ceylon: A General Description . . . ${ }^{75}$ His account of the British conquest of the island is a polemic on the evils of imperialism and a plea for the dignity of man. He enlarged the scope of his earlier volume on Ceylon's environment with chapters describing the Dutch cinnamon monopoly of the seventeenth and eighteenth centuries, the dislodgement of the Dutch by the British East India Company in the 1790s, and the punitive wars (1803-1805, 1815-1818) waged by the English against the defiant native Kingdom of Kandy.

Although Marshall claimed that 'the object of the Author has been chiefly to narrate facts and to record events, not to discuss the policy of that measure [the English conquest], or the merits of the means applied to that effect,' 76 he nevertheless severely castigated the British military intervention in Ceylon as 'a war of devastation ... . for the express purpose of laying waste wherever [English soldiers] were able to penetrate and of destroying whatever could be destroyed.'77 Scorning the inhumane treatment of the natives by the British, Marshall pointed out 'that the incursions of our troops into the Kandyan territory ... . were calculated to fill the population with the most unfavourable opinions of our justice ...., and to confirm the worst prejudices against the European race."78 Both 'Christian and Heathen' committed atrocities, Marshall admitted, but he expected some restraint in warfare by his own countrymen, even against ferocious natives. 'Numerous villages were

"2 Army schools had been authorized during the Napoleonic Wars under the auspices of the Duke of York, but they had been eliminated by economy measures and by public apathy during the 1820 s. Thomas Macaulay, Secretary at War (1839-1841) tried in vain to revive regimental schooling. In 1846 a Corps of Army Schoolmasters was created which numbered 75 teachers on the eve of the Crimean War.

"Cited in N. Br. Rev., 1853, 19, p. 217.

76 The complete title is Ceylon: A General Description of the Island and Its Inhabitants; With An Historical Sketch of the Conquest of the Colony by the English, London, William H. Allen, 1846.

7 Ibid., p. vi.

71 Ibid., p. 120.

7 Ibid., p. 121. 


\section{Richard L. Blanco}

burned, and large tracts of country were reduced to desolation. The English, no doubt, palliated their barbarities by the losses they had incurred during the invasion of 1803 , but who can justify retaliation when the innocent are the victims?'79

According to Marshall, the British Governor of Ceylon, Lt.-General Sir Robert Brownrigg, was dissatisfied with the Treaty of 1805 which ended the First Kandyan War and which left a remnant of territorial sovereignty to the Kandyans; therefore, he deliberately instigated another war in 1815 in order to obliterate the last vestige of native rule on the island. 'It appears not to have been at the time deemed expedient to promulgate the real object of the war, which was obviously to destroy the national existence of the Kandyan government altogether, and to annexe the country to the British crown.' ${ }^{80}$ Although the official pretext for this conquest was supposedly the inevitable march of progress and civilization, in contrast to the despotic rule of the Kandyan king, Marshall denounced the British scheme 'as a cloak to cover versions of glory, renown, and grasping ambition ... as it were to constitute ourselves avengers or guardians of the globe $\ldots .{ }^{81}$

Beaten by the British in 1815, the undaunted Kandyans rebelled in 1817, and nearly ejected the whites from the island. But the disciplined British regiments withstood the native seiges and retaliated by slaughtering 10,000 natives and destroying scores of villages. After such devastation against the Ceylonese, Marshall claimed, it would be impossible 'to establish a cordial or social union with them. ${ }^{82}$ Thoroughly ashamed at the bloody record of pillage levied on a helpless native population in these wars of pacification, the embittered old surgeon concluded that even the tenets of Christianity had little effect 'in either promoting peace and goodwill among men and nations, or meliorating the horrors and barbarities of political strife.' Marshall terminated his history of Ceylon by asking: 'Will the time ever arrive when Christians will no longer be the destroyers of Christians, the destroyers of their fellow men?'83

Although it is difficult to judge the contemporary influence of Marshall's commentary, particularly in an era when European imperialistic adventures were supposedly not politically feasible or fashionable, his work is still cited in modern histories of Ceylon. Utilizing evidence from eye-witnesses on the island, and from his own records as a surgeon on harrowing expeditions into the jungle, Marshall provided future anti-imperialists of the late nineteenth century with a documented history of a shameful episode of colonial race relations in the East Indies. His second book on Ceylon, therefore, was an advocacy for the dignity of man, even as in this case for the pagan of another colour, that was a literary trademark of his thought.

Henry Marshall, 'the father of military medical statistics', ${ }^{84}$ and the spokesman for the rank and file, was a historic link between earlier army sanitarians-Sir John Pringle (1707-1782), Richard Brocklesby (1722-1797), Donald Munro (1727-1802)-and army reformers like Sidney Herbert, Secretary at War (1845-1846, 1852-1855) and Secretary for War (1859-1861), and Florence Nightingale who played a vital part during the Crimean War in improving the health and welfare of the army. In such reforms, Tulloch,

79 Ibid., p. 131.

81 Ibid., p. 149.

${ }^{83}$ Ibid., p. 215.

84 Edinb. med. surg. J., 1847, 67, 256.
${ }^{80}$ Ibid., p. 148.

82 Ibid., p. 226. 


\section{Henry Marshall (1775-1851) and the Health of the British Army}

now a Colonel, had a significant role, ${ }^{85}$ for he was appointed by Lord Panmure (formerly Fox Maule), Secretary for War (1855-1858) to investigate the reasons for the collapse of the supply system to troops at Balaclava. ${ }^{86}$ And, in 1859 when the army established a Statistical Branch of the Medical Department, Balfour, now a deputy surgeongeneral, was responsible for the forthcoming annual reports on the health of soldiers. ${ }^{87}$

Thus, Marshall's colleagues amplified his pioneering work. Although he was not decorated by the Crown for his services, Marshall received some glowing tributes. From the United States came the news that the Regents of the University of the State of New York conferred the honorary degree of Doctor of Medicine on Marshall on 13 May 1847. 'Yours is the first instance,' wrote Dr. Theodore R. Beck, Secretary of the Regents in Albany, New York, 'in which the honorary degree of M.D. has been conferred on the mere motion of the Regents. They grant the same degree to four individuals every year, on the nomination of the State Medical Society, but these are physicians residing within the State . . ${ }^{88}$ The same year, the Edinburgh Medical and Surgical Journal proclaimed: 'If any man is entitled to a distinguished mark of gratitude of the medical officers of the army, of the soldiers, and of the country at large, it is Henry Marshall.' ${ }^{\prime 8}$ And in 1851, this journal asserted that 'it was a happy coincidence that he lived to witness a complete revolution affected in the course of forty years in the treatment of common soldiers ...' of which 'his own exertions and writings were the main cause'.90

Stricken by a painful disease in his declining years, Marshall in a rare comment about himself, remarked that: 'This is bad, very bad, in its own way as bad as can be, but every thing else is good-my home is happy, my circumstances are good; 1 have always made a little more than I spent . . . my life has been long, happy, busy, and I trust useful, and I have had my fill of it . . .91 This remarkable army surgeon,

${ }^{85}$ For the roles of Herbert, Nightingale, and Tulloch, see Cecil Woodham-Smith, Florence Nightingale, 1820-1910, London, Constable, 1950, pp. 203-9, 260-80; and Zachary Cope, Florence Nightingale and the Doctors, Philadelphia, J. B. Lippincott, 1958, pp. 65-70.

${ }^{86}$ See the Tulloch-M'Neill Commission of Inquiry into the Supplies of the British Army in the Crimea, Sessional Papers (House of Commons), xx, 1856. (Hereafter cited as S.P.).

${ }^{87}$ Balfour, along with William Farr, the noted statistician, were among the members of Herbert's Sanitary Commission (1857-58). See the Report of the Commissioners appointed to inquire into the Regulations Affecting the Sanitary Condition of the Army, the Organization of Military Hospitals, and the Treatment of Sick and Wounded, S.P. (House of Commons), xliii, 1857-58.

${ }^{88}$ Cited in Edinb. med. surg. $J ., 1847,68,266$. In reply to my inquiry about Marshall's academic background and professional medical training, Miss Elizabeth Jack, Reference Librarian at Glasgow University Library, wrote: 'I have investigated all sources of information here, but have been unable to find any records of Dr. Henry Marshall's sojourn here at Glasgow College. He certainly did not graduate and, as medical students did not, at that date, matriculate, his name does not appear on the matriculation roll. He may, nevertheless, have attended the College, as records are not complete for the eighteenth century.' The only other reference that I have discovered about Marshall's formal education was his own statement, quoted by Dr. John Brown: 'Although my elementary education was extremely limited, my professional instruction defective, and my natural talents moderate, I have no reason to complain of my progress in life . . . Spare Hours, Houghton, Mifflin, 1888, p. 177. This work is an American reprint of Brown's Locke and Sydenham and Other Papers.

Edinb. med. surg. J., 1847, 67, 258. io Ibid., 1851, 76, 491.

$9 \mathrm{~N}$. Br. Rev., 1853, 19, p. 222. Marshall left most of his estate of over $£ 4,400$ to his wife, but bequeathed $£ 100$ to Balfour. Confirmation of Inventory of Moveable Assets, Edinburgh Commissary Record of Inventories, vol. 80, pp. 38-45 (photocopied), Scottish Record Office, Edinburgh. To Dr. John Brown of Edinburgh, for possible editing, compilation, or publication, Marshall left his "papers, many memoranda, sketches, statistical tables, and the like which I have written and collected chiefly in the hope of contributing to the common stock of knowledge of medical statistics and to the improvement of the condition of the British soldier.' Trust Disposition and Settlement, Register of Deeds, vol. 880, pp. 398-99 (photocopied), Scottish Record Office, Edinburgh. 
who died in 1851 cherished the thought in his old age that many of his youthful hopes had actually materialized within his lifetime.

\section{ACKNOWLEDGEMENTS}

The author acknowledges the financial assistance of the American Philosophical Society for a research grant during the summer of 1967 which enabled him to initiate a projected study of the Medical Department of the British Army.

The author gratefully acknowledges the aid of the following: Mr. Robin Price, Assistant Librarian in the Wellcome Institute of the History of Medicine, who accumulated material for me on Henry Marshall and who was very generous with his expert advice; Mr. Malcolm Davies, Librarian of the Royal Army Medical Corps Library at Millbank, who provided me with innumerable bibliographical suggestions; Dr. John McKenzie, Professor of Anatomy, Marischal College, Aberdeen, who, on behalf of the Aberdeen Medico-Chirurgical Society of Aberdeen, permitted me to study the papers of Sir James McGrigor; Mr. John Woods and Mr. C. A. Potts, Librarians, Ministry of Defence (Central and Army Library), who acquainted me with the resources of the War Office Library; and the Hon. David Erskine, former editor of the Journal of the Society for Army Historical Research, for permission to utilize the Library of the Royal United Service Institution. 